( 2018 , The Authors. Published by FASS Inc. and Elsevier Inc. on behalf of the American Dairy Science Association ${ }^{\circledR}$.

This is an open access article under the CC BY-NC-ND license (http://creativecommons.org/licenses/by-nc-nd/4.0/).

\title{
Methane production, rumen fermentation, and diet digestibility of Holstein and Jersey dairy cows being divergent in residual feed intake and fed at 2 forage-to-concentrate ratios
}

\author{
D. W. Olijhoek, ${ }^{\dagger}{ }^{1}$ P. Løvendahl,† J. Lassen,† A. L. F. Hellwing, ${ }^{*}$ J. K. Höglund,† M. R. Weisbjerg, ${ }^{*}$ S. J. Noel, ${ }^{*}$ \\ F. McLean, ${ }^{*}$ O. Højberg, ${ }^{*}$ and P. Lund* \\ *Department of Animal Science, AU Foulum, Aarhus University, DK 8830 Tjele, Denmark \\ †Department of Molecular Biology and Genetics, AU Foulum, Aarhus University, DK 8830 Tjele, Denmark
}

\begin{abstract}
Improving feed efficiency of dairy cows through breeding is expected to reduce enteric methane production per unit of milk produced. This study examined the effect of 2 forage-to-concentrate ratios on methane production, rumen fermentation, and nutrient digestibility in Holstein and Jersey dairy cows divergent in residual feed intake (RFI). Before experimental onset, RFI was estimated using a random regression model on phenotypic herd data. Ten lactating Holstein and 10 lactating Jersey cows were extracted from the herd and allocated to a high or low pre-experimental RFI group of 5 animals each within breed. Cows were fed ad libitum with total mixed rations either low (LC) or high (HC) in concentrates during 3 periods in a crossover design with a back-cross and staggered approach. Forage-to-concentrate ratio was 68:32 for LC and 39:61 for HC. Cows adapted to the diets in 12 to $24 \mathrm{~d}$ and feces were subsequently collected on $2 \mathrm{~d}$. Afterward, gas exchange was measured in respiration chambers and rumen liquid was collected once after cows exited the chambers. Pre-experimental RFI was included in the statistical analysis as a class (low and high RFI) or continuous variable. Methane per kilogram of dry matter intake (DMI) was lower for Holsteins than Jerseys and the response to increased concentrate level was more pronounced for Holsteins than Jerseys (27.2 vs.13.8\%); a similar pattern was found for the acetate:propionate ratio. However, methane production per kilogram of energy-corrected milk (ECM) was unaffected by breed. Further, total-tract digestibility of neutral detergent fiber was higher for Jerseys than Holsteins. For RFI as a class variable, DMI, methane production regardless of the expression, and digestibility were unaffected by
\end{abstract}

Received December 13, 2017.

Accepted June 4, 2018.

${ }^{1}$ Corresponding author: Dana.Olijhoek@anis.au.dk
RFI. For RFI as a continuous variable, DMI was lower and methane per kilogram of DMI was higher for cows with negative (efficient) than positive (inefficient) RFI values, and neutral detergent fiber digestibility was higher for Holsteins with negative than positive RFI values, but not for Jerseys. Daily methane production and methane per kilogram of ECM were unaffected by RFI. In conclusion, methane per kilogram of DMI of Jerseys was lowered to a smaller extent in response to the $\mathrm{HC}$ diet than of Holsteins. When pre-experimental RFI was used as a continuous variable, higher methane per kilogram of DMI was found for cows with negative RFI than positive RFI values, but not for methane per kilogram of ECM. These findings call for validation in larger studies.

Key words: feed efficiency, residual feed intake, methane, digestibility, dairy cow

\section{INTRODUCTION}

The livestock sector is responsible for $18 \%$ of the total global anthropogenic greenhouse gas emissions (Steinfeld et al., 2006). Methane is a greenhouse gas having a global warming potential 28 times higher than carbon dioxide over a 100-yr time horizon (IPCC, 2013). Fermentation processes in ruminants lead to the production and emission of methane. Methane represents a loss of feed gross energy and the Intergovernmental Panel on Climate Change uses $6.5 \pm 1.0 \%$ as the default for dairy cows (IPCC, 2006). As also demonstrated by Yan et al. (2010), one attribute of energy-efficient cows is a lower methane production relative to energy intake or milk production. Also, breeding for cattle with high feed efficiencies might lead to a decline in daily enteric methane production due to the positive genetic and phenotypic correlation between daily methane production and residual feed intake (RFI; Nkrumah et al., 2006; de Haas et al., 2011). Because feed costs are the primary expense on dairy farms, improving feed efficiency will increase profitability. 
Feed efficiency can be expressed in various ways, such as feed conversion efficiency (FCE; milk output over feed intake) and RFI. Residual feed intake was first proposed by Koch et al. (1963) as the difference between actual and predicted DMI. Residual feed intake is phenotypically independent of production level and BW. Low RFI animals are considered efficient and eat less than average as predicted from their production level, BW, and physiological state, whereas high RFI animals are inefficient and eat more than the average. Residual feed intake contains all variation which is not captured by the explanatory variables in the DMI prediction model (e.g., BW, BCS, and milk production). This variation includes variation due to genetics, environment, and measurement errors (VandeHaar et al., 2016) and is estimated in a second step in the DMI prediction model by subtracting predicted feed intake from actual feed intake. Recently, Tempelman et al. (2015) proposed a variation on the classic RFI procedure by using a 1-step procedure with a random regression model where random solutions denote RFI.

Animals seem to have considerable variation in phenotypic RFI. Several biological processes might explain variation in RFI, such as feed digestion, feeding patterns (e.g., duration and number of feeding bouts), body composition (fat and protein), metabolic processes, physical activity, and heat increment of feeding. Digestion processes are assumed to account for $10 \%$ of the variation in RFI of beef cattle (Richardson and Herd, 2004). Furthermore, partial regression coefficients of DMI on energy sinks, and thus RFI, vary throughout lactation so that early lactation is not closely related to later lactation stages (Li et al., 2017). However, RFI determined between 61 and 230 DIM had strong positive associations with RFI across the entire lactation (Prendiville et al., 2011).

Breeding for animals that are efficient in feed utilization, have high milk yields, and produce small amounts of methane per unit of product will be beneficial for the production efficiency on farms and the environmental load. In theory, improved feed efficiency decreases daily methane production due to a lower DMI at a given production level (Waghorn and Hegarty, 2011), but decreased methane production (e.g., due to nutritional strategies) does not necessarily improve feed efficiency. However, experimental data are inconsistent on the link between RFI and methane emission, and research has primarily focused on beef cattle (e.g., Nkrumah et al., 2006; Hegarty et al., 2007; McDonnell et al., 2016) rather than on lactating dairy cows (e.g., Münger and Kreuzer, 2008; Waghorn and Hegarty, 2011). To bridge this gap, the current project focused on estimating RFI of Holstein and Jersey dairy cows, and relate that to methane emission. The aims of this project were (1) to examine if Holstein and Jersey dairy cows respond similarly to increased proportion of concentrate in the diet with respect to methane emission, rumen fermentation, and nutrient digestibility; and (2) to study methane emission, rumen fermentation, and nutrient digestibility of cows belonging to high or low RFI groups. We hypothesized that (1) Holstein and Jersey cows would respond to a similar extent in methane emission, rumen fermentation, and diet digestibility to the HC diet; (2) Jersey cows might have a higher methane production per kilogram of DMI related to a higher rumen digestibility compared with Holstein cows; and (3) for both breeds, low RFI cows have a lower methane emission (per day, per kg of DMI, and per kg of ECM) compared with high RFI cows.

\section{MATERIALS AND METHODS}

\section{Experimental Design}

The experiment complied with the Danish Ministry of Justice Law No. 726 (September 9, 1993). The experiment consisted of a crossover design of 3 periods with 10 Danish Holstein and 10 Danish Jersey dairy cows. The animals $(n=20)$ were selected from a research herd (200 cows in total) at the Danish Cattle Research Centre (Foulum, Denmark) based on defining RFI before experimental onset using herd data and subsequently extracting 5 high and 5 low efficient animals for each breed. For details on the research herd see Bossen and Weisbjerg (2009). Residual feed intake has only been determined before the experiment. Preexperimental RFI, DMI, ECM yield, BW, and BCS of the 20 selected cows based on herd data before experimental onset are presented in Table 1 . The low and high RFI groups were divergent in RFI and DMI before the experiment (Table 1). The cows were moved from the herd to a tiestall barn to enable intensive sampling and gas measurements. Cows were grouped into 5 blocks of 4 animals. Each block contained a pair of Holstein and a pair of Jersey cows. Cows within a pair were of contrasting RFI (predefined) and of similar parity (first or older) being close in DIM. Next, cows within pairs were randomly allocated to the experimental diets.

In period 1, half of the cows received the low-concentrate (LC) diet and the other half the high-concentrate $\operatorname{diet}(\mathbf{H C})$, which switched in period 2. Period 3 was a repetition of period 1 except that 1 low RFI Holstein cow remained on the LC diet for technical reasons.

All cows started the experiment on the same day, but only 4 respiration chambers were available. Therefore, adaptation to the experimental diets was between 12 
Table 1. Pre-experimental residual feed intake (RFI), DMI, ECM yield, BW, and BCS of Holstein and Jersey dairy cows $(\mathrm{n}=20)$ belonging to the high and low RFI groups based on herd data and before experimental onset

\begin{tabular}{|c|c|c|c|c|c|c|c|c|c|c|}
\hline \multirow[b]{2}{*}{ Item } & \multirow{2}{*}{$\begin{array}{c}\text { Holstein } \\
\text { Mean } \pm \text { SD }\end{array}$} & \multirow{2}{*}{$\begin{array}{c}\text { Jersey } \\
\text { Mean } \pm \text { SD }\end{array}$} & \multicolumn{2}{|c|}{ Holstein } & \multicolumn{2}{|c|}{ Jersey } & \multirow[b]{2}{*}{ SEM } & \multicolumn{3}{|c|}{$P$-value } \\
\hline & & & $\begin{array}{l}\text { High } \\
\text { RFI }\end{array}$ & $\begin{array}{l}\text { Low } \\
\text { RFI }\end{array}$ & $\begin{array}{l}\text { High } \\
\text { RFI }\end{array}$ & $\begin{array}{l}\text { Low } \\
\text { RFI }\end{array}$ & & Breed & RFI & $\begin{array}{l}\text { Breed } \\
\times \mathrm{RFI}\end{array}$ \\
\hline$\overline{R F I}(\mathrm{~kg} / \mathrm{d})$ & $-0.09 \pm 0.69$ & $0.12 \pm 1.12$ & 0.44 & -0.62 & 0.98 & -0.74 & 0.26 & 0.42 & $<0.001$ & 0.21 \\
\hline DMI (kg/d) & $21.1 \pm 3.00$ & $17.4 \pm 2.19$ & 22.5 & 19.8 & 19.0 & 15.9 & 1.01 & 0.001 & 0.01 & 0.79 \\
\hline $\mathrm{ECM}(\mathrm{kg} / \mathrm{d})$ & $36.4 \pm 5.62$ & $30.6 \pm 4.14$ & 38.2 & 34.6 & 31.3 & 30.0 & 2.24 & 0.02 & 0.30 & 0.62 \\
\hline $\mathrm{BW}(\mathrm{kg})$ & $647 \pm 63.1$ & $469 \pm 21.5$ & 648 & 646 & 469 & 470 & 22.3 & $<0.001$ & 0.97 & 0.97 \\
\hline
\end{tabular}

and $24 \mathrm{~d}$ in period 1 . Gas measurements were taken during $72 \mathrm{~h}$ in period 1 (first day was used to adapt the cows to the respiration chambers). In period 2 and 3 , the cows adapted to the diets for $12 \mathrm{~d}$ followed by $48 \mathrm{~h}$ in the respiration chambers.

\section{Animals and Housing}

Cows were housed in individual tiestalls covered with mats and crushed straw pellets during the adaptation period. Four cows were moved to the tiestall barn where the respiration chambers were located half a day before they entered the respiration chambers.

Eight cows were in first parity and 12 cows in second or third parity. Average \pm standard deviations of DIM at the start of the experiment were $187 \pm 39 \mathrm{~d}$, which is within a range of DIM, which is stable in RFI (Prendiville et al., 2011; Li et al., 2017). Average BW at the start of the experiment was $663 \pm 71 \mathrm{~kg}$ for Holstein cows and $487 \pm 35 \mathrm{~kg}$ for Jersey cows.

\section{Diets and Feeding}

Nordic Feed Evaluation System (NorFor; Volden, 2011) was used to formulate the rations. The diets were based on grass clover silage, barley, rapeseed cake, and soybean meal (Table 2). Diets were formulated to obtain forage:concentrate ratios (F:C ratio) of $68: 32$ on $\mathrm{DM}$ basis for the LC diet and 39:61 for the HC diet. Cows were fed twice a day (0615 and $1530 \mathrm{~h}$ ) ad libitum with an expected level of refusals of 1 to $2 \mathrm{~kg}$ of feed DM per cow per day. Feed intake was determined on a daily basis by collection of feed residues. Samples of TMR and feed residues were collected for nutrient analysis and calculation of DMI on $2 \mathrm{~d}$ before a block of cows entered the respiration chambers and every day during chamber stay. Feed ingredients were collected once weekly. Samples of TMR and ingredients were pooled per period, and feed residues were pooled per cow per period. Total mixed rations, feed ingredients, and feed residues were analyzed for DM, nitrogen, NDF, indigestible NDF (iNDF), starch, crude fat, and ash.

\section{Sampling and Measurements}

Body weight of the cows was measured at the beginning of the experiment and when cows entered and left the respiration chambers. Cows were milked twice a day at 0615 and $1530 \mathrm{~h}$ in connection with feeding. Milk yield and composition were determined once weekly based on 2 subsequent milkings. During chamber stay, milk yield was recorded at each milking and ECM calculated per day.

Feces were collected from each cow twice per day $(0800$ and $1530 \mathrm{~h})$ on 2 subsequent days before cows

Table 2. Dietary and chemical composition $(\mathrm{g} / \mathrm{kg}$ of DM, unless noted) as analyzed for the low-concentrate (LC) and high-concentrate (HC) diets

\begin{tabular}{|c|c|c|}
\hline Item & $\mathrm{LC}$ & $\mathrm{HC}$ \\
\hline$\overline{\mathrm{F}: \mathrm{C} \text { ratio }^{1}}$ & $68: 32$ & $39: 61$ \\
\hline \multicolumn{3}{|l|}{ Dietary composition } \\
\hline Grass/clover silage & 684 & 391 \\
\hline Barley & 189 & 377 \\
\hline Rapeseed cake & 25.7 & 51.4 \\
\hline Soybean meal, dehulled & 85.7 & 171 \\
\hline Urea & 4.7 & 2.7 \\
\hline Mineral premix ${ }^{2}$ & 9.3 & 5.3 \\
\hline Vitamin premix ${ }^{3}$ & 2.1 & 1.2 \\
\hline \multicolumn{3}{|l|}{ Chemical composition } \\
\hline $\mathrm{DM}(\mathrm{g} / \mathrm{kg})$ & 513 & 620 \\
\hline Ash & 72.0 & 57.3 \\
\hline $\mathrm{CP}$ & 170 & 204 \\
\hline Crude fat & 31.8 & 33.6 \\
\hline Starch & 105 & 218 \\
\hline NDF & 335 & 271 \\
\hline $\mathrm{iNDF}^{4}$ & 45.3 & 41.8 \\
\hline Gross energy $^{5}(\mathrm{MJ} / \mathrm{kg}$ of DM) & 18.7 & 19.2 \\
\hline
\end{tabular}

${ }^{1} \mathrm{~F}: \mathrm{C}$ ratio $=$ forage:concentrate ratio.

${ }^{2}$ Vitamin and mineral concentration per kilogram DM of feedstuff: 176 $\mathrm{g}$ of chloride, $140 \mathrm{~g}$ of magnesium, $120 \mathrm{~g}$ of calcium, $120 \mathrm{~g}$ of sodium, $1.5 \mathrm{~g}$ of potassium, $0.5 \mathrm{~g}$ of sulfur, $4,500 \mathrm{mg}$ of zinc, $4,000 \mathrm{mg}$ of manganese, 1,500 mg of copper, $225 \mathrm{mg}$ of iodine, $50 \mathrm{mg}$ of selenium, 25 $\mathrm{mg}$ of cobalt, $600,000 \mathrm{IU}$ of vitamin A, 190,000 IU of vitamin $\mathrm{D}_{3}$, and $4,000 \mathrm{IU}$ of vitamin E.

${ }^{3}$ Vitamin and mineral concentration per kilogram DM of feedstuff: 10 $\mathrm{mg}$ of selenium, 5,000,000 IU of vitamin A, 200,000 IU of vitamin D, and 10,000 IU of vitamin E.

${ }^{4} \mathrm{iNDF}=$ indigestible NDF.

${ }^{5}$ Calculated according to NorFor (Volden and Nielsen, 2011). 
entered the respiration chambers. Subsamples (approximately $350 \mathrm{~g}$ per sample) were pooled per cow per period. Feces were analyzed for DM, nitrogen, NDF, iNDF, starch, crude fat, and ash.

Four transparent polycarbonate respiration chambers were used to measure gas exchange based on the open-circuit indirect calorimetry system as described by Hellwing et al. (2012). The system recorded flow and concentrations of outlet gases $\left(\mathrm{CH}_{4}, \mathrm{CO}_{2}, \mathrm{O}_{2}\right.$, and $\mathrm{H}_{2}$ ) with 12.5-min intervals (Columbus Instruments, Columbus, $\mathrm{OH}$ ), temperature, humidity, and pressure (Veng Systems, Roslev, Denmark). The chambers were placed in a square to allow cows to face each other. Milking, feeding, and cleaning occurred simultaneously to minimize staff accessing the chambers.

Calculations for gas exchange were based on standard conditions for temperature and pressure $\left[0^{\circ} \mathrm{C}(273.15 \mathrm{~K})\right.$ and $101.325 \mathrm{kPa}$. Recovery tests for $\mathrm{CH}_{4}$ and $\mathrm{CO}_{2}$ were performed before and after the experiment. Measured gas concentrations were corrected with an average recovery value \pm standard error of $100.4 \pm 1.06 \%$ for $\mathrm{CH}_{4}$ and $97.7 \pm 2.06 \%$ for $\mathrm{CO}_{2}$.

Cows had access to feed until they were removed from the chambers and rumen liquid was sampled as soon as possible afterward, followed by feeding of the cows. Rumen liquid was obtained by inserting a transesophageal sampling device (FLORA rumen scoop, Geishauser, Guelph, Canada) into the rumen (Geishauser et al., 2012). Fifteen to $40 \mathrm{~mL}$ of rumen liquid was extracted and stored at $-20^{\circ} \mathrm{C}$ until analysis for VFA.

\section{Laboratory Analyses}

Feed, residues, and fecal samples were stored at $-20^{\circ} \mathrm{C}$ until laboratory analysis. Feed and residue samples were dried at $60^{\circ} \mathrm{C}$ for $48 \mathrm{~h}$ to determine DM (Åkerlind et al., 2011). All samples were freeze-dried and ground before chemical analysis. All samples were ground on a 1-mm screen, except samples for starch analysis, which were ground on a $0.5-\mathrm{mm}$ screen and iNDF analysis for which a $1.5-\mathrm{mm}$ screen on a cutter mill was used. The ash content was determined by combustion at $525^{\circ} \mathrm{C}$ for $6 \mathrm{~h}$. The nitrogen content was analyzed by the Dumas method (Hansen, 1989) using a Vario MAX CN (Elementar Analysesysteme GmbH, Hanau, Germany). The nitrogen content was multiplied by 6.25 to obtain the $\mathrm{CP}$ content. To analyze the crude fat content, samples were first hydrolyzed with $\mathrm{HCl}$ (Stoldt, 1952) and afterward crude fat was extracted with petroleum ether using a Soxtec 2050 (Foss Analytical, Hillerød, Denmark). Starch was analyzed using heat stable $\alpha$-amylase and amyloglucosidase and assayed for glucose according to the method described by Kristensen et al. (2007) using a YSI model 2900 analyzer (YSI Inc., Yellow
Springs, OH). Neutral detergent fiber was analyzed with a Fibertec M6 System (Foss Analytical, Hillerød, Denmark) using heat-stable amylase and sodium sulfite and reported as ash-free NDF (Mertens, 2002). The iNDF content was expressed as residual NDF after 288 $\mathrm{h}(12 \mathrm{~d})$ incubation in Dacron bags with a pore size of $12 \mu \mathrm{m}$ in the rumen of 3 heifers fed a standard ration at maintenance level (Ak kerlind et al., 2011). The F:C ratio was $67: 33$ on a DM basis and the $\mathrm{CP}$ content was 139 $\mathrm{g} / \mathrm{kg}$ of DM. The ration included a forage part consisting of two-thirds grass/clover hay and one-third barley straw, and a concentrate part consisting of pellets per $100 \mathrm{~kg}$ of fresh feed composed of $40 \mathrm{~kg}$ of barley, $40 \mathrm{~kg}$ of oats, $10 \mathrm{~kg}$ of soybean meal, $3 \mathrm{~kg}$ of rapeseed meal, $3 \mathrm{~kg}$ of sugar beet molasses, and $4 \mathrm{~kg}$ of a commercial mineral mixture (per $100 \mathrm{~g}: 6 \mathrm{~g}$ of Ca, $10 \mathrm{~g}$ of P, $12 \mathrm{~g}$ of $\mathrm{Mg}, 5 \mathrm{~g}$ of Na; Type 3, Vitfoss, Gråsten, Denmark). Cows were fed equal portions twice a day.

Rumen liquid was analyzed for VFA as described by Canibe et al. (2007) using a Hewlett Packard gas chromatograph model 6890 (Agilent Technologies Inc., Wilmington, DE) with a flame ionization detector and a 30-m SGE BP1 column (Scientific Instrument Services, Ringoes, NJ). Milk was analyzed for protein, lactose, and fat content by an infrared analyzer (Milkoscan Msc4000, Foss Analytical) at Eurofins Steins Laboratories (Vejen, Denmark).

\section{Calculations and Statistical Analyses}

To select 10 low and 10 high RFI animals for the experiment, data of 1,068 lactating cows (605 Holstein, 295 Jersey, 168 Danish Red) calving between 2002 and 2014 were used to obtain the DMI prediction equation and estimate phenotypic RFI. Two hundred out of the 1,068 cows were potentially available at the research herd (for details on the facilities see Bossen and Weisbjerg, 2009). Pre-experimental RFI was estimated from a 1-step procedure including fixed and random effects according to Tempelman et al. (2015) using Proc HPMixed in SAS (version 9.3, SAS Institute Inc., Cary, NC). Dry matter intake was regressed on various energy sinks using the equation below. Random solutions for cow nested within breed defined the pre-experimental RFI values.

$$
\begin{gathered}
\text { DMI }=\mu+\text { breed }+ \text { parity }+ \text { breed } \times \text { parity } \\
+\beta_{1} \Delta \mathrm{BW}(\text { breed })+\beta_{2} \mathrm{BW}^{0.75}(\text { breed }) \\
+\beta_{3} \Delta \mathrm{BCS}(\text { breed })+\beta_{4} \mathrm{ECM}(\text { breed })+\text { WOL } \\
+ \text { WOL } \times \text { breed } \times \text { parity }+ \text { cohort }+ \text { cow }(\text { breed }) \\
+ \text { cow }(\text { breed }, \text { parity })+\varepsilon
\end{gathered}
$$


where DMI is observed DMI; $\mu$ is the intercept; breed is Holstein, Jersey, or Danish Red; and parity is 1 to 3. The parameter $\Delta \mathrm{BW}$ is daily $\mathrm{BW}$ change, $\mathrm{BW}^{0.75}$ is metabolic BW (MBW), $\triangle \mathrm{BCS}$ is daily BCS change, and ECM is ECM yield, and all are nested within breed. Week of lactation (WOL), the interaction between WOL, breed, and parity, and the cohort (76 management groups of different smaller experiments and diets) were included in the model. All previously described parameters were included as fixed effects. The random effects were cow nested within breed and cow nested within breed and parity. The residuals from the model are denoted with $\varepsilon . \beta_{1}$ is the partial regression coefficient of DMI on $\triangle \mathrm{BW}$ ( $\beta_{1}$ is 0.12 for Holstein, 0.06 for Jersey, and 0.09 for Danish Red), $\beta_{2}$ is the partial regression coefficient of DMI on MBW ( $\beta_{2}$ is 0.11 for Holstein, 0.08 for Jersey, and 0.12 for Danish Red), $\beta_{3}$ is the partial regression coefficient of DMI on $\triangle \mathrm{BCS}$ $\left(\beta_{3}\right.$ is 53.8 for Holstein, 60.8 for Jersey, and 83.3 for Danish Red), and $\beta_{4}$ is the partial regression coefficient of DMI on ECM ( $\beta_{4}$ is 0.16 for Holstein, 0.18 for Jersey, and 0.21 for Danish Red). Daily BW change and $\triangle \mathrm{BCS}$ were estimated using a third-order Legendre polynomial against week of lactation and was fitted for each cow per parity. Predicted values from the regression were obtained, and the first derivative denotes $\Delta \mathrm{BW}$ and $\triangle \mathrm{BCS}$.

From the experimentally obtained data, daily DMI was calculated as DM offered minus DM of feed residues. Nutrient intakes of ash, OM, CP, crude fat, NDF, iNDF, and starch were calculated as the nutrient intake with feed subtracted with the amount of nutrients in residues. Indigestible NDF was used as an internal marker to calculate fecal DM flow. Digestibilities (apparent total-tract digestibility) of DM, OM, CP, NDF, crude fat, and starch were calculated from the respective nutrient intake and fecal flow. Gross energy intake (GEI) was calculated according to the Nordic feed evaluation system (Volden and Nielsen, 2011). The following equation reported by Sjaunja et al. (1991) was used to calculate ECM yield $(3.14 \mathrm{MJ} / \mathrm{kg})$ : ECM yield $(\mathrm{kg} / \mathrm{d})=$ milk yield $(\mathrm{kg} / \mathrm{d}) \times[(38.3 \times$ milk fat $(\mathrm{g} / \mathrm{kg})+24.2 \times$ milk protein $(\mathrm{g} / \mathrm{kg})+15.71 \times$ milk lactose $(\mathrm{g} / \mathrm{kg})+20.7) / 3,140]$, where lactose is lactose monohydrate.

The absolute concentrations of VFA and ammonia, and rumen $\mathrm{pH}$ were deleted from the statistical analysis due to the possibility of contamination of the rumen liquid samples with saliva. Molar proportions of VFA were regarded as valid and kept in the statistical analysis. Lactate concentrations in rumen liquid were below the detection limit $(0.24 \mathrm{mmol} / \mathrm{L})$ of the analysis and therefore omitted.
Pre-experimental data for RFI, DMI, ECM yield, BW, and BCS of the 20 cows were analyzed with Proc Mixed in SAS. The model included breed (Holstein and Jersey), pre-experimental RFI (low and high), and their interaction as fixed effects, and cow nested within pre-experimental RFI and breed as random effect.

From experimentally obtained data, DMI on $2 \mathrm{~d}$ before entering the chambers and 2 or $3 \mathrm{~d}$ while in the chambers were compared using the paired-samples $t$-test (60 observations) and was found not statistically different $(P=0.69)$. Therefore, observations for DMI were averaged per cow per period to obtain 60 observations in total. Observations of daily gas production, milk yield, and composition during chamber stay, VFA, and digestibility were also averaged to 60 observations before statistical analysis. Experimental data were analyzed with Proc Mixed. The model included the fixed effects of diet (LC and $\mathrm{HC}$ ), breed (Holstein and Jersey), pre-experimental RFI as a class variable (low and high), parity (1 to 3 ), period (1 to 3 ), and all 2-way interactions between breed, pre-experimental RFI, and diet. Block and cow nested within block, breed, pre-experimental RFI, and parity were included as random effects. In the former statistical analysis, RFI has been treated as a fixed effect; however, RFI is a continuous trait and using RFI as a continuous variable in the statistical model might influence the conclusions. Therefore, the analysis was repeated, but now using pre-experimental RFI as a continuous variable (pre-experimental random solutions from the random regression model predicting DMI). Proc Reg was used to obtain $R^{2}$ values of the regression of several key traits against RFI as a continuous variable.

Least squares means and SEM are presented in the tables. Significance was declared at $P \leq 0.05$ and a tendency at $0.05<P \leq 0.10$.

\section{RESULTS}

\section{Concentrate Level}

Cows had a higher DMI when fed the HC diet compared with the LC diet $(P<0.001)$ and a higher DMI per $\mathrm{kg}$ of MBW $(P<0.001$; Table 3$)$. Milk and ECM yield were also higher for the $\mathrm{HC}$ than the LC diet (for both $P<0.001)$. The increased concentrate proportion was accompanied by an increased milk protein content $(P=0.001)$ and a decreased milk fat content $(P=$ $0.001)$.

Molar proportion of acetate in rumen VFA and the ratio between acetate and propionate $(\mathbf{A}: \mathbf{P}$ ratio) were lower for the HC than the LC diet (for both $P<0.001$; Table 4), whereas the highest molar proportions of 
RESIDUAL FEED INTAKE AND METHANE PRODUCTION
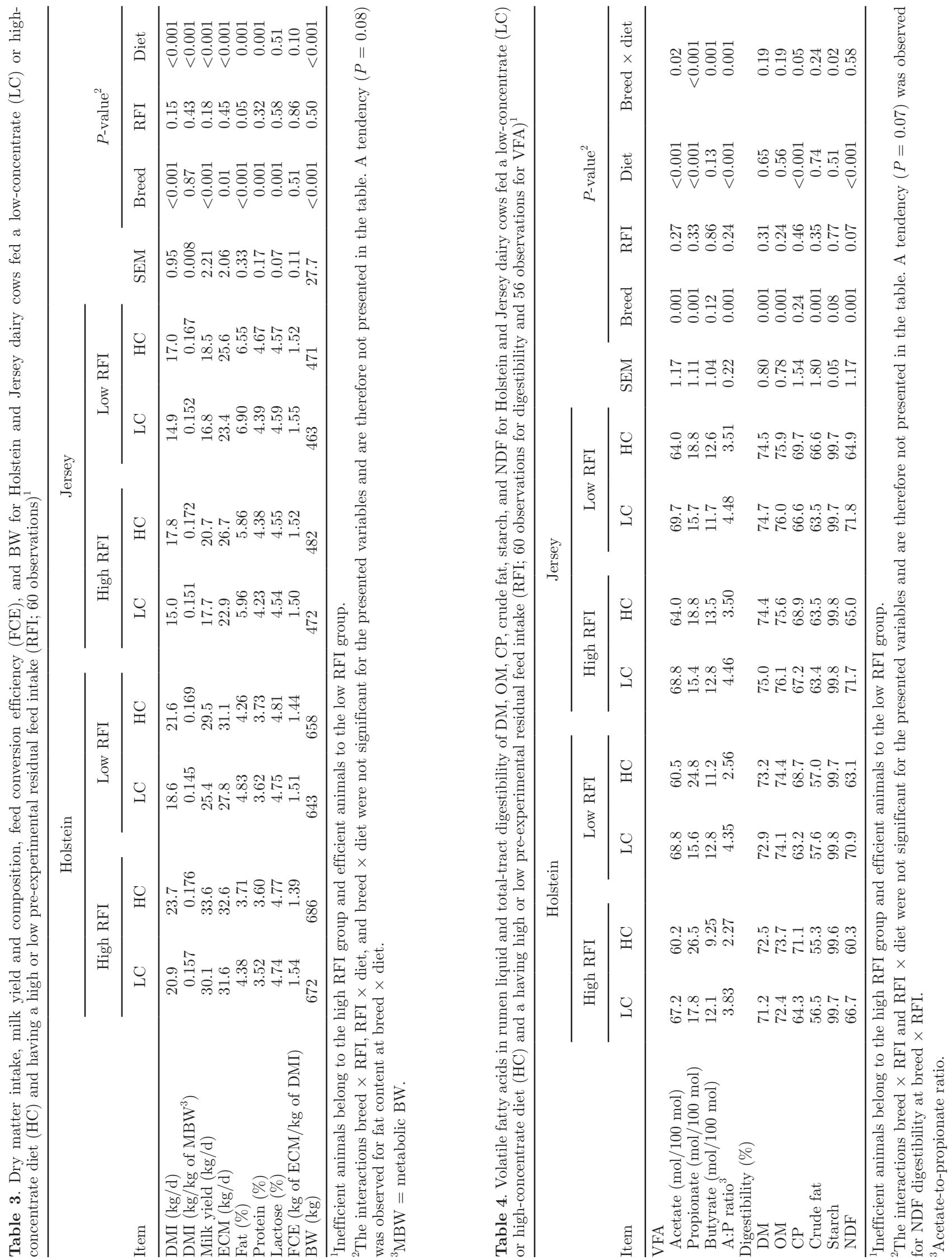
propionate were observed for the HC $\operatorname{diet}(P<0.001)$. Butyrate molar proportion was unaffected by the dietary concentrate level.

Digestibility of $\mathrm{CP}$ was lower for the LC than the HC diet $(P<0.001$; Table 4$)$, whereas NDF digestibility was higher for the LC compared with the $\mathrm{HC}$ diet $(P<0.001)$. Other digestibilities were unaffected by concentrate level.

Methane production expressed either on a daily basis, per kilogram of DMI, as a percentage of GEI, or per kilogram of ECM, was lower when the HC diet was fed than for the LC diet (Table 5; for all $P<0.001$ ). Methane production per kilogram of DMI, hereafter referred to as methane yield, was on average 32.1 and $25.5 \mathrm{~L}$ of $\mathrm{CH}_{4} / \mathrm{kg}$ of DMI for the LC and $\mathrm{HC}$ diets, respectively, which corresponds to a decline in methane yield by $20.6 \%$ when the concentrate proportion was increased. Methane production per kilogram of ECM, hereafter referred to as methane intensity, was on average 21.3 and $17.8 \mathrm{~L} / \mathrm{kg}$ of ECM for the LC and $\mathrm{HC}$ diets, respectively. Increased concentrate proportion was also accompanied by an increase in $\mathrm{CO}_{2}$ production and $\mathrm{O}_{2}$ consumption (for both $P<0.001$ ).

\section{Breed and Interactions Between Breed and Concentrate Level}

Dry matter intake was higher for Holstein than Jersey cows $(P<0.001)$, but DMI per kilogram of MBW did not differ between breeds (Table 3 ).

Molar proportion of acetate was higher for Jersey than Holstein cows $(P<0.01$ Table 4$)$ and the HC diet decreased molar proportion of acetate more in Holstein cows than in Jersey cows (interaction $P=0.02$ ). Molar proportion of propionate was lower for Jersey than Holstein cows $(P=0.001)$ and the HC diet increased molar proportion of propionate to a larger extent in Holstein cows than in Jersey cows (interaction $P<0.001$ ).

Digestibilities of DM and OM were higher for Jersey than Holstein cows (both $P=0.001$; Table 4). Jersey cows also had a higher NDF digestibility compared with Holstein cows $(P=0.001 ; 68.4 \%$ for Jersey vs. $65.3 \%$ for Holstein). Similarly, the fat digestibility was higher for Jersey cows compared with Holstein cows $(P$ $<0.001)$.

Holstein cows produced more methane per day than Jersey cows $(P=0.01)$. However, methane yield and methane as a percentage of GEI were higher for Jersey cows than Holstein cows $(P=0.001$ and $P=0.01$, respectively). The HC diet lowered daily methane production and methane yield to a greater extent in Holstein cows than in Jersey cows by (for both: interaction $P<$ 0.001; Table 5). Methane yield was lowered with $27.2 \%$ and $13.8 \%$ for Holstein and Jersey cows, respectively,

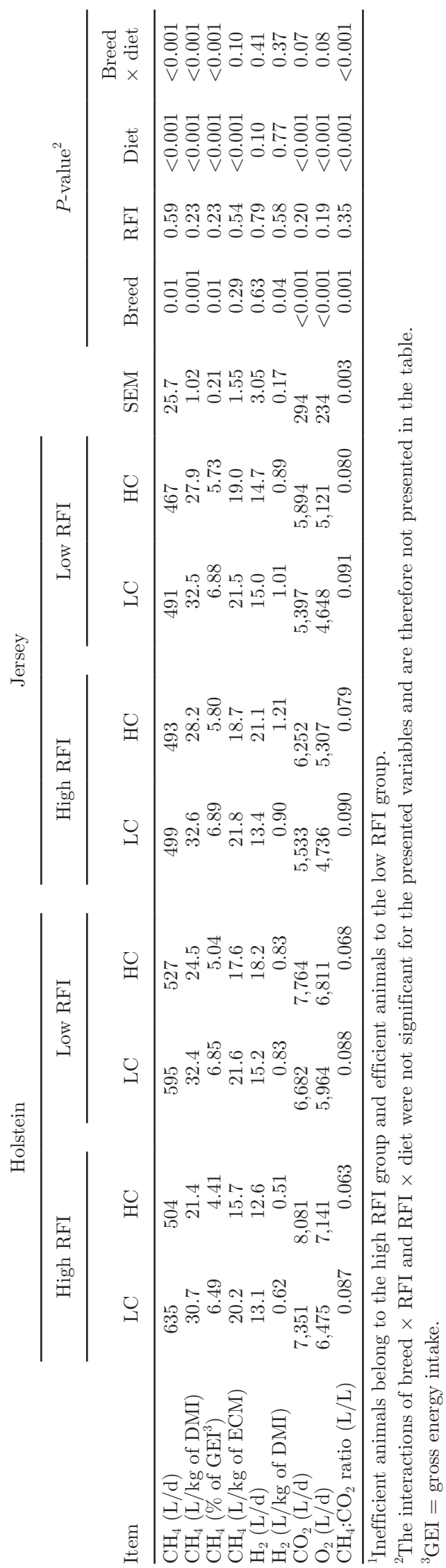


when the concentrate proportion was increased. Methane intensity was not significantly affected by breed or the interaction between breed and diet. Furthermore, Jersey cows emitted more hydrogen per kilogram of DMI compared with Holstein cows $(P=0.04)$.

\section{Residual Feed Intake}

Dry matter intake, DMI per kilogram of MBW, ECM yield, and FCE did not differ between the groups of low and high RFI (pre-experimental) cows (Table 3). The milk fat content was higher for low RFI cows compared with high RFI cows $(P=0.05)$. Additionally, rumen fermentation characteristics and digestibility of dietary components were unaffected by RFI (Table 4). Digestibility of NDF only tended $(P=0.07)$ to be higher for low RFI cows (i.e., efficient cows) compared with high RFI cows (i.e., inefficient cows) and similar NDF digestibility coefficients were observed for Jersey cows between both RFI groups. Moreover, methane production, regardless of the expression, was also unaffected by RFI (pre-experimental; Table 5).

Additional analyses have been made by plotting several key traits against the continuous RFI (preexperimental) values (Figure 1). When RFI was decreased with $1 \mathrm{~kg}$ of $\mathrm{DMI} / \mathrm{d}$ (i.e., cows become more efficient) then DMI decreased $(P=0.01)$ with $2.1,2.3$, 0.2 , and $0.7 \mathrm{~kg} / \mathrm{d}$ for Holstein cows on the LC diet (HLC), Holstein cows on the HC $\operatorname{diet}(\mathbf{H H C})$, Jersey cows on the LC $\operatorname{diet}(\mathbf{J L C})$, and Jersey cows on the HC diet $(\mathbf{J H C})$, respectively (Figure 1a). Larger declines in DMI were observed for Holstein compared with Jersey cows and for the HC compared with the LC diet. Energy-corrected milk yield (Figure 1b) was unaffected by RFI as a main effect; however, a significant interaction was observed between RFI and breed $(P=0.04)$ with partial regression coefficients of $-4.0,-4.1,1.0$, and $0.0 \mathrm{~kg}$ of $\mathrm{ECM} / \mathrm{d}$ per $1 \mathrm{~kg}$ of DMI/d decrease in RFI for HLC, HHC, JLC, and JHC, respectively. The NDF digestibility increased $(P=0.03)$ with 3.2 and $2.1 \%$ per $1 \mathrm{~kg}$ of DMI/d decrease in RFI for HLC and HHC, respectively, whereas partial regression coefficients for JLC and JHC were 0.1 and $-0.1 \%$, respectively (Figure 1c). Daily methane production was unaffected by RFI (Figure 1d). However, decreasing RFI values increased methane yield $(P=0.01$; Figure 1e). Partial regression coefficients for methane yield were 1.5, 2.9, 0.4, and $0.2 \mathrm{~L}$ of $\mathrm{CH}_{4} / \mathrm{kg}$ of DMI per $1 \mathrm{~kg}$ of DMI/d decrease in RFI for HLC, HHC, JLC, and JHC, respectively. Methane intensity was also unaffected by RFI (Figure 1f). Residual feed intake explained 7 to $44 \%$ and 4 to $41 \%$ of the variation in all dependent variables together for HLC and HHC, respectively. For JLC and JHC, only 1 to $10 \%$ and 1 to $9 \%$ of the variation in the pooled de- pendent variables was explained by RFI, respectively. Thus, RFI explained more variation in the dependent variables for Holsteins than for Jerseys. It should be noted that most $R^{2}$ values were not significant.

\section{DISCUSSION}

\section{Effects of Forage-to-Concentate Ratio}

A well-known methane mitigation strategy is to increase proportions of concentrate in the diet of dairy cows, especially above 35 to $40 \%$ of the diet (Sauvant and Giger-Reverdin, 2009), although exceptions occur where methane emissions have been increased (Beever et al., 1988). In the current study, methane production, regardless of the expression, was lowered in response to the HC diet (Table 5) with largest declines for Holstein cows. Aguerre et al. (2011) reported a linear decrease in methane yield of up to $19 \%$ across $\mathrm{F}$ : $\mathrm{C}$ ratios ranging from 68:32 to 47:53 (on a DM basis). Methane emission is lowered when diets high in grain, and thereby starch, are fed due to the diversion of hydrogen into propionate fermentation resulting in less hydrogen being available for methanogenesis (Moss et al., 2000). Propionate molar proportions are not necessarily affected by increased dietary concentrate level (Aguerre et al., 2011), probably because molar proportions reflect a balance between production and absorption, rather than production alone. On the other hand, high forage diets, and thereby NDF, stimulate acetate fermentation, which results in a net increase in hydrogen production and consequently also in methane emissions (Moss et al., 2000). In the current study, the highest acetate molar proportion was observed for the LC diet. Also, propionate proportion was highest on the $\mathrm{HC}$ diet and the $\mathrm{A}: \mathrm{P}$ ratio was lower for the $\mathrm{HC}$ diet than $\mathrm{LC}$ diet, which has also been reported previously (Agle et al., 2010). Interestingly, the largest declines in methane yield in response to the $\mathrm{HC}$ diet were observed for Holstein cows. This finding, together with the VFA profiles, indicates that an increased concentrate proportion may be more effective as a methane mitigation strategy for Holstein than Jersey cows. Although inclusion of high levels of concentrate in the diet of dairy cows is an effective methane mitigation strategy, it has disadvantages associated with grain production, such as increased greenhouse gas emissions and high feed costs (Boadi et al., 2004).

Feeding high levels of concentrate caused a decrease in the digestibility of NDF, which has been widely reported previously (e.g., Nousiainen et al., 2009; Agle et al., 2010). Diets high in concentrates are generally easily digestible and will lower the rate of NDF degradation in the rumen. Moreover, NDF originating from 
a) $\quad \operatorname{diet} P<0.001$, breed $P<0.001$, RFI $P=0.01$, diet $\times$ breed $P=0.41$,

a) $\quad$ RFI $\times \operatorname{diet} P=0.22$, and RFI $\times$ breed $P=0.10$

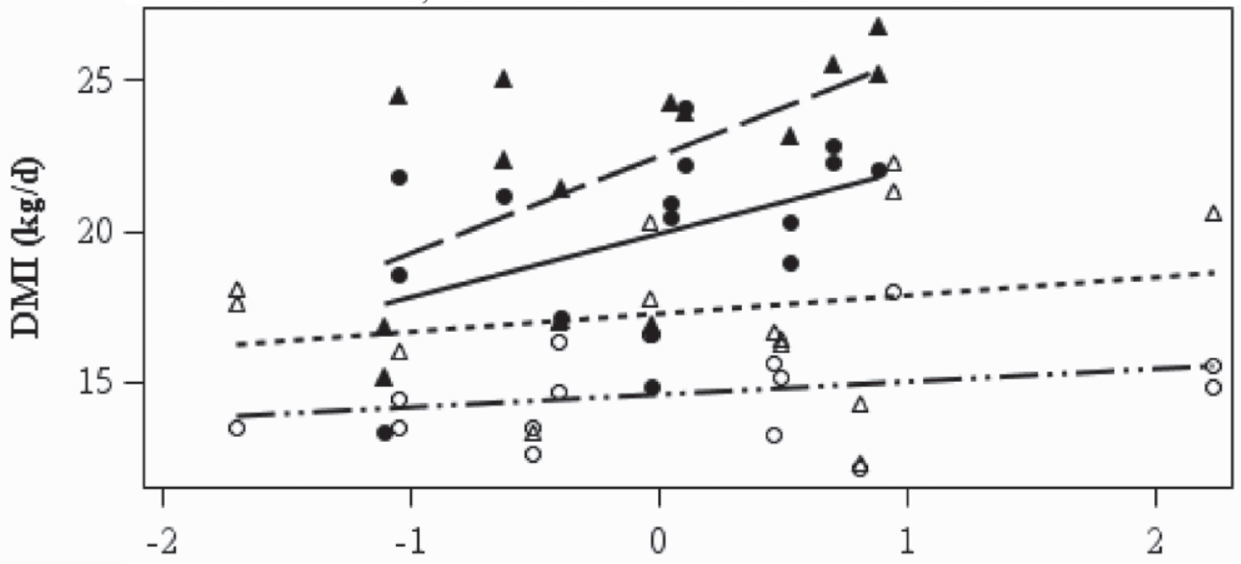

b) $\quad \operatorname{diet} P<0.001$, breed $P=0.001$, RFI $P=0.12$, diet $\times$ breed $P=0.55$,

b) $\quad$ RFI $\times \operatorname{diet} P=0.23$, and $\mathrm{RFI} \times \operatorname{breed} P=0.04$

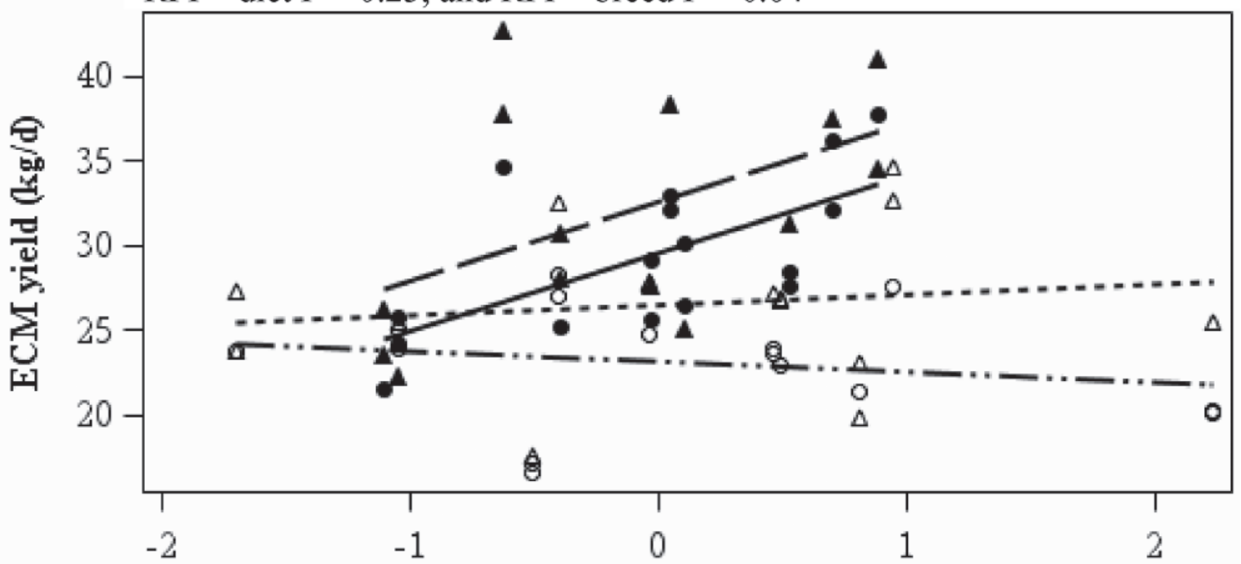

diet $P<0.001$, breed $P=0.001$, RFI $P=0.03$, diet $\times$ breed $P=0.65$,

c) RFI $\times \operatorname{diet} P=0.73$, and RFI $\times$ breed $P=0.03$

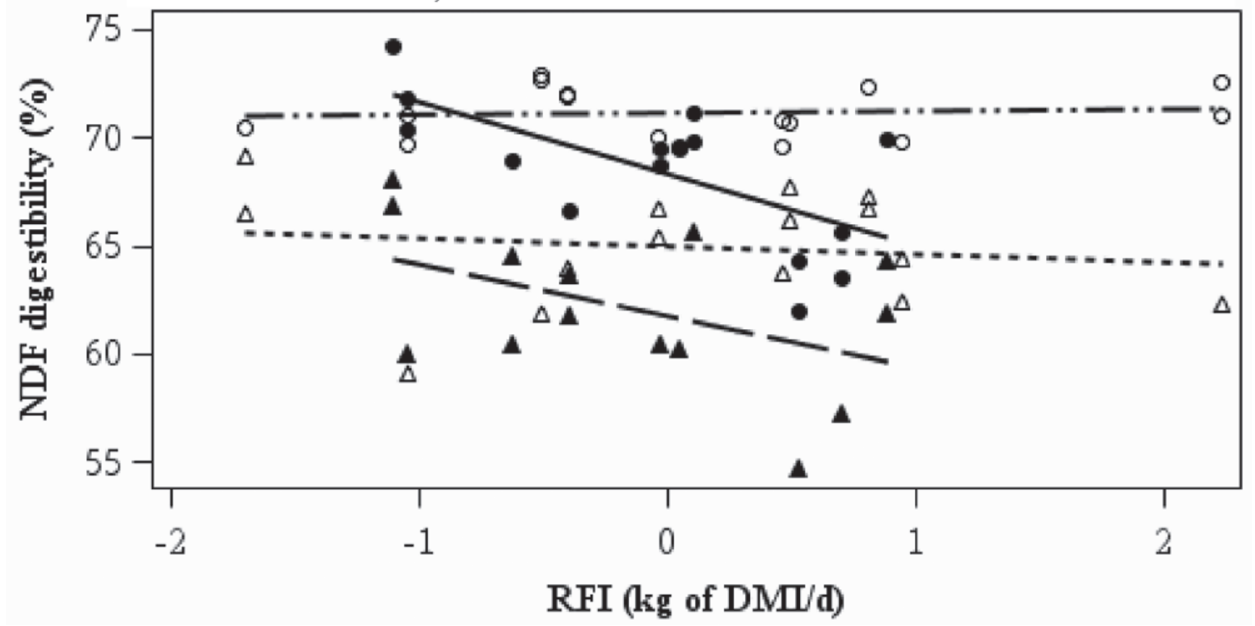

Figure 1. Effects of residual feed intake (RFI) seen as a continuous predictor for key traits (60 observations). Dry matter intake (a), ECM yield (b), total-tract digestibility of $\mathrm{NDF}$ (c), daily methane production (d), methane yield ( $\mathrm{L}$ of $\mathrm{CH}_{4} / \mathrm{kg}$ of DMI; e), and methane intensity (L of $\mathrm{CH}_{4} / \mathrm{kg}$ of ECM; f) across pre-experimental residual feed intake (RFI) for Holstein dairy cows fed a low-concentrate (LC) diet (solid line with filled circles), Holstein dairy cows fed a high-concentrate (HC) diet (long dashed line with filled triangles), Jersey dairy cows fed a LC diet (dashed and dotted line with open circles), and Jersey dairy cows fed a HC diet (short dashed line with open triangles). Efficient animals have negative RFI values and inefficient animals have positive RFI values. 
d) $\quad \operatorname{diet} P<0.001$, breed $P=0.01$, RFI $P=0.39$, diet $\times$ breed $P<0.001$,

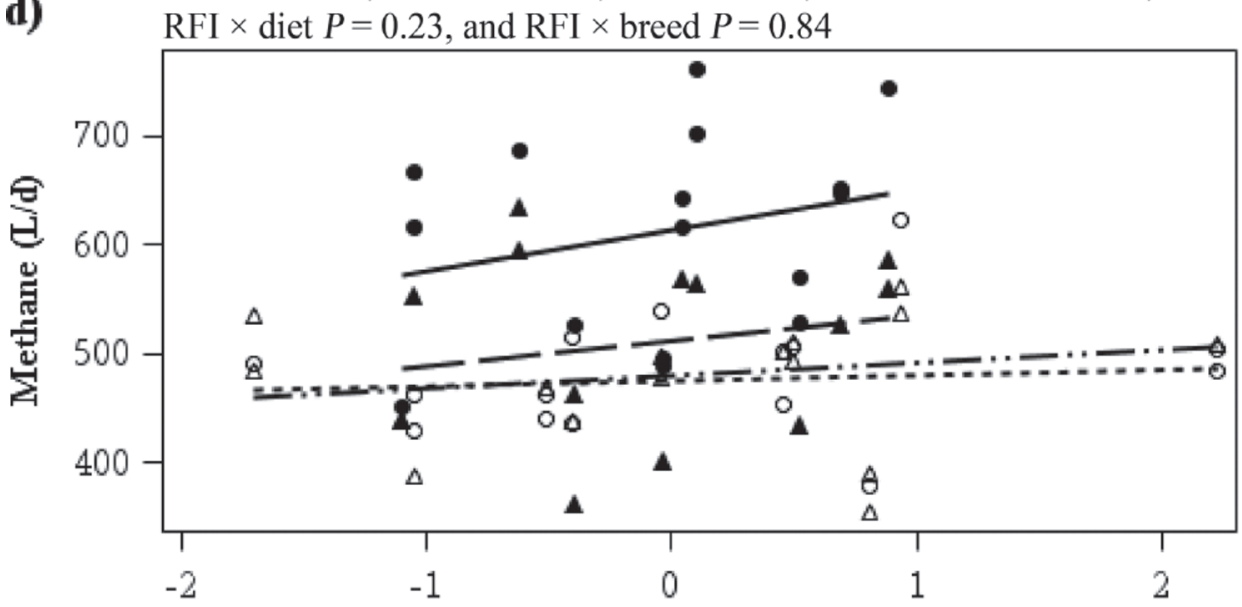

e) $\operatorname{diet} P<0.001$, breed $P=0.001$, RFI $P=0.01$, diet $\times$ breed $P<0.001$,

e) $\quad$ RFI $\times \operatorname{diet} P=0.32$, and RFI $\times$ breed $P=0.07$

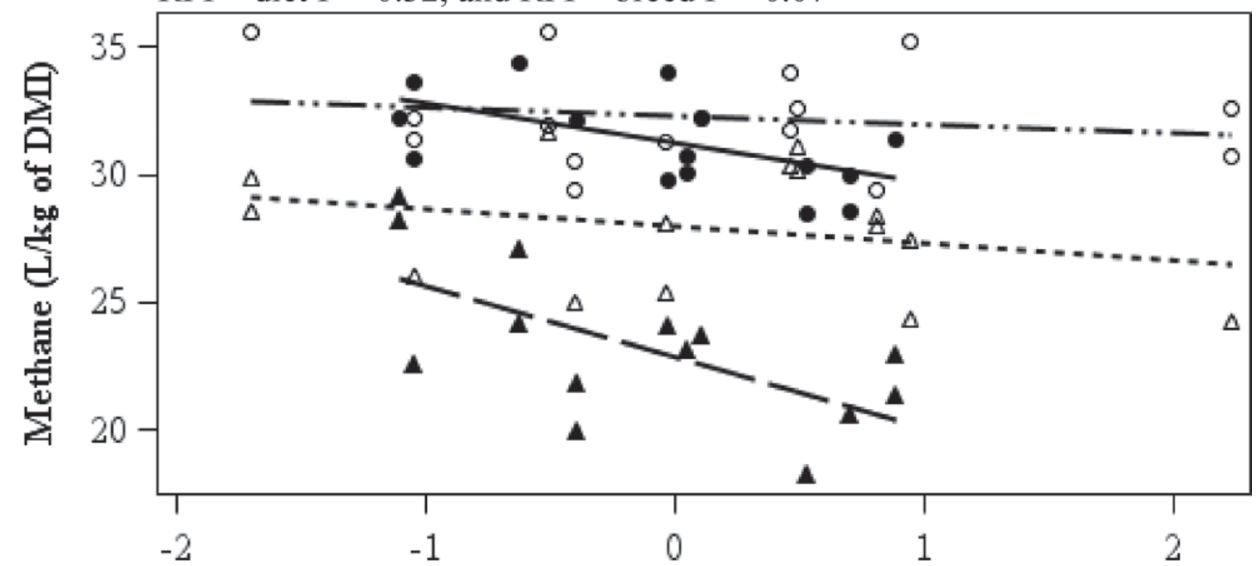

fiet $P<0.001$, breed $P=0.17$, RFI $P=0.20$, diet $\times$ breed $P=0.05$,
RFI $\times \operatorname{diet} P=0.06$, and RFI $\times$ breed $P=0.04$

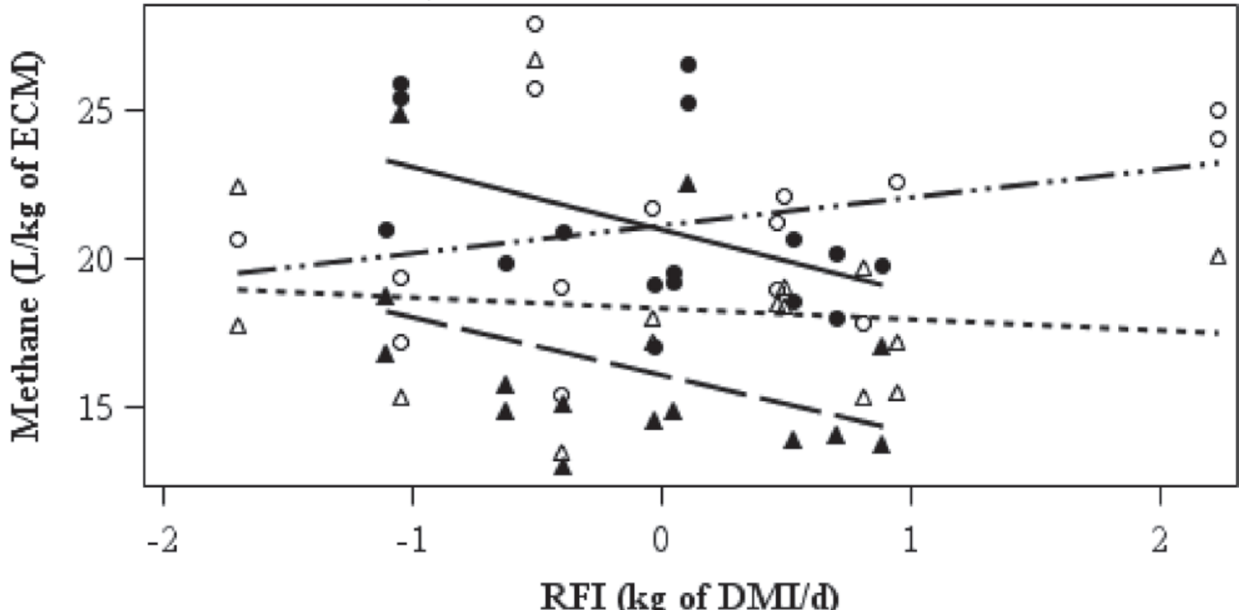

Figure 1 (Continued). Effects of residual feed intake (RFI) seen as a continuous predictor for key traits (60 observations). Dry matter intake (a), ECM yield (b), total-tract digestibility of NDF (c), daily methane production (d), methane yield ( $\mathrm{L}_{\text {of }} \mathrm{CH}_{4} / \mathrm{kg}$ of DMI; e), and methane intensity ( $\mathrm{L}$ of $\mathrm{CH}_{4} / \mathrm{kg}$ of ECM; f) across pre-experimental residual feed intake (RFI) for Holstein dairy cows fed a low-concentrate (LC) diet (solid line with filled circles), Holstein dairy cows fed a high-concentrate (HC) diet (long dashed line with filled triangles), Jersey dairy cows fed a LC diet (dashed and dotted line with open circles), and Jersey dairy cows fed a HC diet (short dashed line with open triangles). Efficient animals have negative RFI values and inefficient animals have positive RFI values. 
concentrates usually contains a higher iNDF fraction compared with NDF originating from forages. As a consequence, the potential digestibility of NDF for the $\mathrm{HC}$ diet was lower than the $\mathrm{LC} \operatorname{diet}(84.6 \%$ for $\mathrm{HC}$ vs. $86.5 \%$ for LC), which only partly explains the difference in NDF digestibility between diets.

Another finding of the current experiment was the observation that cows tended to sort their feed, especially the HC diet. Therefore, feed residues have been analyzed for all nutrients and a correction for composition of feed residues was made in the calculation of nutrient intake and digestibility coefficients.

The presence of highly digestible nutrients in $\mathrm{HC}$ diets enabled an increased DMI and together with the high energy density of the $\mathrm{HC}$ diet milk production was increased. The milk protein content was increased as well due to the higher energy intake when high proportions of concentrate were fed. Also, lower fat content in milk was observed for the $\mathrm{HC}$ diet, suggesting that the lower NDF digestibility led to less available substrate (i.e., acetate and butyrate) for milk fat synthesis. However, the total supply of acetate and butyrate as milk fat precursors might not have been reduced due to increased DMI. These effects of increased concentrate proportions on milk yield and composition have also been demonstrated in a modeling study by Huhtanen and Hetta (2012).

\section{Differences Between Breeds}

It was hypothesized that breed differences in methane emission and diet digestibility exist between Holstein and Jersey dairy cows, and that both breeds respond in a similar way to the $\mathrm{HC}$ diet. Jersey cows were found to have a higher methane yield and lost more methane energy as a proportion of GEI than Holstein cows, but not on a daily basis and as methane intensity (Table 5 ). Differences in daily methane production have been observed between dairy and beef cattle breeds, but no differences have been reported for methane yield (Münger and Kreuzer, 2006; Rooke et al., 2014). In terms of methane yield, Holstein cows seem to benefit most from a $\mathrm{HC}$ diet due to the larger reduction in methane yield $(27.2 \%)$ compared with Jersey cows $(13.8 \%)$ and this is most likely caused by the higher acetate molar proportion, lower propionate proportion, and smaller reduction in $\mathrm{A}: \mathrm{P}$ ratio in response to the HC diet for Jersey cows compared with Holstein cows. The higher methane and higher hydrogen production per kilogram of DMI of Jersey cows rather than Holstein cows reflects more enteric gas production relative to feed intake, which indicates a more intense fermentation in the rumen that favors hydrogen production rather than consumption. Previously, no difference in
A:P ratio of Holstein and Jersey cows was observed when animals were fed diets differing in fat and rumen undegradable protein content (Rodriguez et al., 1997). Rumen fermentation patterns of Holstein and Jersey cows on the same diet regimen have not been studied in detail, but difference in rumen fermentation might be related to the microbial community structure.

The higher methane yield of Jersey cows was also accompanied by higher total-tract digestibility of $\mathrm{OM}$ and NDF. When pre-experimental RFI was decreased with $1 \mathrm{~kg}$ of $\mathrm{DMI} / \mathrm{d}$ then the NDF digestibility of Holstein cows increased with 3.2 and $2.1 \%$ for the LC and $\mathrm{HC}$ diet, respectively, whereas no effect was seen among Jersey cows (Figure 1c). Neutral detergent fiber digestibilities for high and low RFI Jersey cows on the same diet were similar, suggesting that Jersey cows in general digest NDF at maximum capacity within the physiological constraints of the digestive tract, such as rumen capacity, total digestive tract capacity, and passage rate. Ingvartsen and Weisbjerg (1993) observed a $21 \%$ higher passage rate through the entire digestive tract with the use of external markers in primiparous Jersey cows compared with Holstein cows, but no difference in $\mathrm{OM}$ digestibility, suggesting that digestion rate is higher in Jerseys than in Holsteins. Likewise, Aikman et al. (2008) observed a higher passage rate through the rumen and total tract for Jersey cows than Holstein cows and a higher NDF digestibility when using Cr-mordanted grass silage, but no difference in digestibility of $\mathrm{OM}$ and other nutrients. Beecher et al. (2014) observed higher digestibilities of OM and NDF for Jersey cows compared with Holstein-Friesian cows. Thus, Jersey cows are efficient in utilizing dietary fiber, probably due to a higher chewing rate per unit of feed consumed (Aikman et al., 2008) and a larger gastrointestinal tract weight relative to BW than Holstein cows (Beecher et al., 2014). Further, Jersey cows had a greater DMI per $100 \mathrm{~kg}$ of BW (Ingvartsen and Weisbjerg, 1993). However, DMI per kilogram of MBW of the cows in the current study did not differ between breeds, which is in agreement with Aikman et al. (2008). Overall, the anatomy and physiology of Jersey cows seem to make them better suited for digestion of NDF (with coinciding rumen VFA profile) than Holstein cows, which subsequently makes diets high in concentrate less effective for reducing methane emissions from Jersey cows.

Interestingly, all 6 panels in Figure 1 show that the Jersey cows responded less strongly (i.e., lower $\mathrm{R}^{2}$ values and partial regression coefficients) than Holstein cows in the dependent variable to a change in RFI (preexperimental) despite the limited number of animals used. For example, methane yield of Jersey cows on both diets is fairly stable across RFI values and this 
coincides with a similar pattern in NDF digestibility. For Jersey cows the dependent variables related less strongly to RFI than Holsteins, which could be because they already are highly efficient animals. Danish Jersey cows have been reported to be more feed efficient ( $\mathrm{kg}$ of $\mathrm{ECM} / \mathrm{kg}$ of DMI) than Danish Holstein cows based on commercial herd data (Kristensen et al., 2015). Some studies reported higher feed utilization efficiencies for Jerseys than large breeds (e.g., Holstein cows; Oldenbroek, 1988; Grainger and Goddard, 2004).

\section{Methane Production and Residual Feed Intake}

In this study, cows were allocated to high or low RFI groups based on performance before the experiment. For the experimental design, a high and a low RFI cow were paired within breed according to parity and DIM to balance the design. Although the low and high RFI groups were significantly different in RFI before the experiment, there was an overlap in RFI between both groups, which could mask some significant effects on variables. Therefore, daily methane production, methane yield, methane intensity, and some selected variables were also regressed against continuous RFI to evaluate whether more information could be extracted from this study. It is shown that the 2 statistical analyses, using RFI groups and continuous ranking, give different interpretations to the effect of RFI on methane yield, DMI, and NDF digestibility, as will be discussed below. It should also be noted that the possibility exists that ranking of cows with respect to RFI may differ between management conditions (research herd vs. experimental conditions).

It was hypothesized that low RFI cows have lower methane emissions (per day, methane yield, and methane intensity) compared with high RFI cows. When considering the pre-experimental RFI groups, this hypothesis could not be confirmed because daily methane production, methane yield, methane intensity, and methane losses as a proportion of GEI did not differ between low and high RFI dairy cows. Dry matter intake did not differ between low and high RFI cows as well, despite observed differences in pre-experimental DMI (Table 1). Similarly, Waghorn and Hegarty (2011) reported no difference in DMI, daily methane production, and methane yield between RFI groups for heifers and lactating Holstein Friesian cows. Higher methane yield for low RFI than high RFI beef cattle has been reported previously (McDonnell et al., 2016). Further, low RFI beef cattle have been shown to produce less methane per day than high RFI animals, but not as methane yield, and this could be directly related to the reduced DMI of low RFI animals (Hegarty et al.,
2007; Fitzsimons et al., 2013). In contrast, methane per kilogram of MBW and as percentage of GEI were lower for low RFI beef cattle, which was independent of DMI, since animals were fed restrictedly (Nkrumah et al., 2006). Literature appears inconsistent on the relation between RFI and methane production expressed in different units, and the relationship between RFI and daily methane production seems to be affected by level of feed intake.

When considering RFI (pre-experimental) as a continuous ranking, no effect of RFI on daily methane production and methane intensity was observed (Figure 1d and 1e). However, DMI increased and methane yield decreased with increasing RFI values despite the low number of cows used in this study. The lower DMI of cows with negative RFI values probably lead to a lower passage rate of digesta through the digestive tract compared with cows with positive RFI values, which in turn increased digestibility of NDF. The higher NDF digestibility of cows with negative RFI values did not lead to an increase in daily methane production probably due to compensation by a lower DMI. Consequently, methane yield was higher for cows with negative RFI rather than cows with positive RFI values. Thus, we were unable to confirm our hypothesis that low RFI animals have a lower methane emission (per day, methane yield, and methane intensity).

Münger and Kreuzer (2008) also used RFI as a continuous variable in the statistical analysis and found that RFI correlated weakly and positively with daily methane production and methane yield $(\mathrm{r}=0.24$ for $\mathrm{g}$ of $\mathrm{CH}_{4} / \mathrm{d}$ and $\mathrm{r}=0.26$ for $\mathrm{g}$ of $\mathrm{CH}_{4} / \mathrm{kg}$ of DMI). Fitzsimons et al. (2013) reported a tendency for a weak negative correlation $(\mathrm{r}=-0.27)$ between RFI and methane yield. Daily methane production of beef cattle has also been reported to increase with decreasing RFI, which is in contrast to the expectation (Freetly and Brown-Brandl, 2013).

A strategy to reduce methane emission could be breeding for efficient animals. Based on modeling, Yan et al. (2010) concluded that selection for high energy utilization efficiencies could be a promising methane mitigation strategy because increasing milk yield, increasing the energetic efficiency of milk production, and lowering maintenance energy costs of dairy cattle can reduce the proportion of methane energy lost per gross energy, digestible energy, or ME, as well as methane per unit of milk production. However, this study and previous work by McDonnell et al. (2016) suggests that breeding for cattle with improved feed efficiency might lead to higher methane yield, which calls for more research in this area before a final conclusion can be drawn. 


\section{Diet Digestibility and Residual Feed Intake}

Diet digestibility was not found to differ between low and high RFI (pre-experimental) cows, except for NDF (tendency; Table 4). Cows with negative RFI values emitted more methane per kilogram of DMI, which could be related to the higher NDF digestibility of cows with negative RFI values compared with positive RFI values (Figure 1c). Fermentation of NDF in the rumen stimulates acetate production, which leads to the production of hydrogen that could subsequently be used by Archaea to produce methane. However, this principle is not reflected in the observed acetate molar proportion in the current study. Unaltered molar proportions of acetate and butyrate have been reported for beef heifers, as well as lower propionate molar proportion of low RFI cattle compared with high RFI contemporaries fed with grass silage (McDonnell et al., 2016). In agreement with our study, Potts et al. (2017) observed a tendency for a higher NDF digestibility in low RFI dairy cattle compared with high RFI dairy cattle. In the current study, no difference in digestibility of other nutrients was observed between RFI groups. Other studies also did not observe differences in total-tract digestibilities between RFI groups of dairy cows (Thornhill et al., 2014) and beef cattle (Cruz et al., 2010; Lawrence et al., 2011; Fitzsimons et al., 2013; Lawrence et al., 2013). However, higher digestibilities of several nutrients for low RFI rather than high RFI cattle have been observed previously (Nkrumah et al., 2006; Rius et al., 2012; McDonnell et al., 2016). Further, a negative correlation $(\mathrm{r}=-0.30)$ between DM digestibility and RFI has been observed and nutrient digestibility explained 9 to $31 \%$ of the variation in RFI for diets low in starch, whereas no correlation was observed for diets high in starch (Potts et al., 2017). This finding suggests that the relation between DM digestibility and RFI is related to diet type and the associated differences in feed intake level (Potts et al., 2017). Overall, the reduced feed intake of low RFI cows probably results in improved fermentation and digestibility of nutrients and thus a more efficient conversion of gross energy into net energy.

The lower DMI of Holsteins with negative RFI values (Figure 1a) might explain the lower ECM yield compared with Holsteins with positive RFI values (Figure 1b) because DMI and milk yield are highly related. However, it was unexpected that Holstein cows with negative RFI values produced less milk compared with Holstein cows with positive RFI values, and no effect of pre-experimental RFI on ECM yield of Jerseys was observed. When RFI was included as class variable, then no difference in ECM yield was observed. It was not unexpected that FCE did not differ between RFI groups, because FCE and RFI are different measures of feed efficiency based on different estimation methods.

\section{Implications}

More research is needed, especially for dairy cows, on the relationship between RFI and methane emission. Due to the lacking and somewhat contradictory results reported in the literature, more uniformity in the methane expressions should be adopted to enable a better comparison between studies. Here we suggest reporting methane production at least per kilogram of ECM and per kilogram of DMI for dairy cows. Future research should also focus on examining effects of RFI on methane emission when cows are ranked on a continuous scale according to RFI values. Furthermore, more life cycle assessment studies are needed to evaluate the carbon footprint of dairy production as a whole and not only addressing enteric methane emission from different diets, and ensuring more productive efficient practices.

\section{CONCLUSIONS}

The response to increased concentrate feeding differed between breeds as methane yield (methane per $\mathrm{kg}$ of DMI) was lowered to a larger extent for Holstein cows than for Jersey cows when the concentrate proportion in the diet was increased. This corresponded with a higher reduction in the rumen acetate:propionate ratio for Holstein cows compared with Jersey cows when increasing levels of dietary concentrate were fed. Methane intensity (methane per $\mathrm{kg}$ of ECM) did not differ between Holstein and Jersey dairy cows. Pre-experimental RFI gave no response in methane emissions and other biological processes when RFI was used as a class variable. When pre-experimental RFI was used as a continuous variable, methane intensity was unaffected by RFI, but cows with negative RFI values had a lower DMI, higher digestibility of NDF, and higher methane yield than cows with positive RFI values. Therefore, RFI as a continuous variable seems to be a more appropriate strategy for analyzing effects of RFI.

\section{ACKNOWLEDGMENTS}

The authors thank Torkild N. Jakobsen (Aarhus University Foulum, Tjele, Denmark) and the barn staff for their skillful assistance during the experiment and the laboratory technicians for analyzing the samples. We also thank Suraya Salleh (University of Copenhagen, Copenhagen, Denmark) and Gareth Difford (Aarhus University Foulum, Tjele, Denmark) for their assistance during sampling and Marianne Johansen (Aarhus University Foulum, Tjele, Denmark) for her assistance dur- 
ing initiation of the experiment. This study was funded by the Danish Milk Levy Fund (Aarhus, Denmark) and Aarhus University, and was part of the Nordic Feed Efficiency project.

\section{REFERENCES}

Agle, M., A. N. Hristov, S. Zaman, C. Schneider, P. M. Ndegwa, and V. K. Vaddella. 2010. Effect of dietary concentrate on rumen fermentation, digestibility, and nitrogen losses in dairy cows. J. Dairy Sci. 93:4211-4222.

Aguerre, M. J., M. A. Wattiaux, J. M. Powell, G. A. Broderick, and C. Arndt. 2011. Effect of forage-to-concentrate ratio in dairy cow diets on emission of methane, carbon dioxide, and ammonia, lactation performance, and manure excretion. J. Dairy Sci. 94:3081-3093.

Aikman, P. C., C. K. Reynolds, and D. E. Beever. 2008. Diet digestibility, rate of passage, and eating and rumination behavior of Jersey and Holstein cows. J. Dairy Sci. 91:1103-1114.

Åkerlind, M., M. R. Weisbjerg, T. Eriksson, R. Thøgersen, P. Udén, B. L. Ólafsson, O. O. M. Harstad, and H. Volden. 2011. Feed analyses and digestion methods. Pages 41-54 in NorFor-The Nordic feed evaluation - system. EAAP publication no. 130. H. Volden, ed. Wageningen Academic Publishers, Wageningen, the Netherlands.

Beecher, M., F. Buckley, S. M. Waters, T. M. Boland, D. EnriquezHidalgo, M. H. Deighton, M. O'Donovan, and E. Lewis. 2014. Gastrointestinal tract size, total-tract digestibility, and rumen microflora in different dairy cow genotypes. J. Dairy Sci. 97:3906-3917.

Beever, D. E., S. B. Cammell, C. Thomas, M. C. Spooner, M. J. Haines, and D. L. Gale. 1988. The effect of date of cut and barley substitution on gain and on the efficiency of utilization of grass silage by growing cattle. 2. Nutrient supply and energy partition. Br. J. Nutr. 60:307-319.

Boadi, D., C. Benchaar, J. Chiquette, and D. Massé. 2004. Mitigation strategies to reduce enteric methane emissions from dairy cows: Update review. Can. J. Anim. Sci. 84:319-335.

Bossen, D., and M. R. Weisbjerg. 2009. Allocation of feed based on individual dairy cow live weight changes II: Effect on milk production. Livest. Sci. 126:273-285.

Canibe, N., O. Hojberg, J. H. Badsberg, and B. B. Jensen. 2007. Effect of feeding fermented liquid feed and fermented grain on gastrointestinal ecology and growth performance in piglets. J. Anim. Sci. 85:2959-2971.

Cruz, G. D., J. A. Rodriguez-Sanchez, J. W. Oltjen, and R. D. Sainz. 2010. Performance, residual feed intake, digestibility, carcass traits, and profitability of Angus-Hereford steers housed in individual or group pens. J. Anim. Sci. 88:324-329.

de Haas, Y., J. J. Windig, M. P. L. Calus, J. Dijkstra, M. de Haan, A. Bannink, and R. F. Veerkamp. 2011. Genetic parameters for predicted methane production and potential for reducing enteric emissions through genomic selection. J. Dairy Sci. 94:6122-6134.

Fitzsimons, C., D. A. Kenny, M. H. Deighton, A. G. Fahey, and M. McGee. 2013. Methane emissions, body composition, and rumen fermentation traits of beef heifers differing in residual feed intake. J. Anim. Sci. 91:5789-5800.

Freetly, H. C., and T. M. Brown-Brandl. 2013. Enteric methane production from beef cattle that vary in feed efficiency. J. Anim. Sci. 91:4826-4831.

Geishauser, T., N. Linhart, A. Neidl, and A. Reimann. 2012. Factors associated with ruminal $\mathrm{pH}$ at herd level. J. Dairy Sci. 95:45564567 .

Grainger, C., and M. E. Goddard. 2004. A review of the effects of dairy breed on feed conversion efficiency-An opportunity lost? Anim. Prod. Aust. 25:77-80.

Hansen, B. 1989. Determination of nitrogen as elementary-N, an alternative to Kjeldahl. Acta Agric. Scand. Anim. Sci. 39:113-118.

Hegarty, R. S., J. P. Goopy, R. M. Herd, and B. McCorkell. 2007. Cattle selected for lower residual feed intake have reduced daily methane production. J. Anim. Sci. 85:1479-1486.
Hellwing, A. L. F., P. Lund, M. R. Weisbjerg, M. Brask, and T. Hvelplund. 2012. Technical note: test of a low-cost and animal-friendly system for measuring methane emissions from dairy cows. J. Dairy Sci. 95:6077-6085.

Huhtanen, P., and M. Hetta. 2012. Comparison of feed intake and milk production responses in continuous and change-over design dairy cow experiments. Livest. Sci. 143:184-194.

Ingvartsen, K. L., and M. R. Weisbjerg. 1993. Jersey cows have a higher feed intake capacity and higher rate of passage than Friesian cows. Arch. Tierz. 36:495-498.

IPCC. 2006. Agriculture, forestry and other land use: Emissions from livestock and manure management. 2006 IPCC Guidelines for National Greenhouse Gas Inventories 4, 10.1-10.87.

IPCC. 2013. Climate change 2013: The physical science basis. Working Group I contribution to the fifth assessment report of the Intergovernmental Panel on Climate Change. T. F. Stocker, D. Qin, G. K. Plattner, M. M. B. Tignor, S. K. Allen, J. Boschung, A. Nauls, Y. Xia, V. Bex, and P. M. Midgley, ed. Cambridge University Press, Cambridge, UK.

Koch, R. M., L. A. Swiger, D. Chambers, and K. E. Gregory. 1963. Efficiency of feed use in beef cattle. J. Anim. Sci. 22:486-494.

Kristensen, N. B., A. Storm, B. M. L. Raun, B. A. Røjen, and D. L. Harmon. 2007. Metabolism of silage alcohols in lactating dairy cows. J. Dairy Sci. 90:1364-1377.

Kristensen, T., C. Jensen, S. Østergaard, M. R. Weisbjerg, O. Aaes, and N. I. Nielsen. 2015. Feeding, production, and efficiency of Holstein-Friesian, Jersey, and mixed-breed lactating dairy cows in commercial Danish herds. J. Dairy Sci. 98:263-274.

Lawrence, P., D. A. Kenny, B. Earley, D. H. Crews Jr., and M. McGee. 2011. Grass silage intake, rumen and blood variables, ultrasonic and body measurements, feeding behavior, and activity in pregnant beef heifers differing in phenotypic residual feed intake. J. Anim. Sci. 89:3248-3261.

Lawrence, P., D. A. Kenny, B. Earley, and M. McGee. 2013. Intake of conserved and grazed grass and performance traits in beef suckler cows differing in phenotypic residual feed intake. Livest. Sci. 152:154-166

Li, B., B. Berglund, W. F. Fikse, J. Lassen, M. H. Lidauer, P. Mäntysaari, and P. Løvendahl. 2017. Neglect of lactation stage leads to naive assessment of residual feed intake in dairy cattle. J. Dairy Sci. 100:9076-9084.

McDonnell, R. P., K. J. Hart, T. M. Boland, A. K. Kelly, M. McGee, and D. A. Kenny. 2016. Effect of divergence in phenotypic residual feed intake on methane emissions, ruminal fermentation, and apparent whole-tract digestibility of beef heifers across three contrasting diets. J. Anim. Sci. 94:1179-1193.

Mertens, D. R. 2002. Gravimetric determination of amylase-treated neutral detergent fiber in feeds with refluxing in beakers or crucibles: Collaborative study. J. AOAC Int. 85:1217-1240.

Moss, A. R., J.-P. Jouany, and J. Newbold. 2000. Methane production by ruminants: Its contribution to global warming. Ann. Zootech. 49:231-253.

Münger, A., and M. Kreuzer. 2006. Methane emission as determined in contrasting dairy cattle breeds over the reproduction cycle. Int. Congr. Ser. 1293:119-122.

Münger, A., and M. Kreuzer. 2008. Absence of persistent methane emission differences in three breeds of dairy cows. Aust. J. Exp. Agric. 48:77-82.

Nkrumah, J. D., E. K. Okine, G. W. Mathison, K. Schmid, C. Li, J. A. Basarab, M. A. Price, Z. Wang, and S. S. Moore. 2006. Relationships of feedlot feed efficiency, performance, and feeding behavior with metabolic rate, methane production, and energy partitioning in beef cattle. J. Anim. Sci. 84:145-153.

Nousiainen, J., M. Rinne, and P. Huhtanen. 2009. A meta-analysis of feed digestion in dairy cows. 1 . The effects of forage and concentrate factors on total diet digestibility. J. Dairy Sci. 92:5019-5030.

Oldenbroek, J. K. 1988. The performance of Jersey cows and cows of larger dairy breeds on two complete diets with different roughage contents. Livest. Prod. Sci. 18:1-17.

Potts, S. B., J. P. Boerman, A. L. Lock, M. S. Allen, and M. J. VandeHaar. 2017. Relationship between residual feed intake and digest- 
ibility for lactating Holstein cows fed high and low starch diets. J. Dairy Sci. 100:265-278.

Prendiville, R., K. M. Pierce, L. Delaby, and F. Buckley. 2011. Animal performance and production efficiencies of Holstein-Friesian, Jersey and Jersey $\times$ Holstein-Friesian cows throughout lactation. Livest. Sci. 138:25-33.

Richardson, E. C., and R. M. Herd. 2004. Biological basis for variation in residual feed intake in beef cattle. 2. synthesis of results following divergent selection. Aust. J. Exp. Agric. 44:431-440.

Rius, A. G., S. Kittelmann, K. A. Macdonald, G. C. Waghorn, P. H. Janssen, and E. Sikkema. 2012. Nitrogen metabolism and rumen microbial enumeration in lactating cows with divergent residual feed intake fed high-digestibility pasture. J. Dairy Sci. 95:50245034 .

Rodriguez, L. A., C. C. Stallings, J. H. Herbein, and M. L. McGilliard. 1997. Diurnal variation in milk and plasma urea nitrogen in Holstein and Jersey cows in response to degradable dietary protein and added fat. J. Dairy Sci. 80:3368-3376.

Rooke, J. A., R. J. Wallace, C.-A. Duthie, N. McKain, S. M. de Souza, J. J. Hyslop, D. W. Ross, T. Waterhouse, and R. Roehe. 2014. Hydrogen and methane emissions from beef cattle and their rumen microbial community vary with diet, time after feeding and genotype. Br. J. Nutr. 112:398-407.

Sauvant, D., and S. Giger-Reverdin. 2009. Modélisation des interactions digestives et de la production de méthane chez les ruminants. INRA Prod. Anim. 22:375-384. (In French).

Sjaunja, L. O., L. Baevre, L. Junkkarinen, J. Pedersen, and J. Setala 1991. A Nordic proposal for an energy corrected milk (ECM) formula. Pages 156-157 in EAAP Publication 50: Performance Recording of Animals: State of the Art 1990. Performance Centre for Agricultural Publishing and Documentation (PUDOC), Wageningen, the Netherlands.

Steinfeld, H., P. Gerber, T. Wassenaar, V. Castel, M. Rosales, and C. de Haan. 2006. Livestock's Long Shadow: Environmental Issues and Options. Food and Agriculture Organization of the United Nations, Rome, Italy.

Stoldt, W. 1952. Vorschlag zur vereinheitlichung der fettbestimmung in lebensmitteln. Fette Seifen 54:206-207. (In German).

Tempelman, R. J., D. M. Spurlock, M. Coffey, R. F. Veerkamp, L. E. Armentano, K. A. Weigel, Y. de Haas, C. R. Staples, E. E. Connor, Y. Lu, and M. J. VandeHaar. 2015. Heterogeneity in genetic and nongenetic variation and energy sink relationships for residual feed intake across research stations and countries. J. Dairy Sci. 98:2013-2026.

Thornhill, J. B., L. C. Marett, M. J. Auldist, J. S. Greenwood, J. E. Pryce, B. J. Hayes, and W. J. Wales. 2014. Whole-tract dry matter and nitrogen digestibility of lactating dairy cows selected for phenotypic divergence in residual feed intake. Anim. Prod. Sci. 54:1460-1464.

VandeHaar, M. J., L. E. Armentano, K. Weigel, D. M. Spurlock, R. J. Tempelman, and R. Veerkamp. 2016. Harnessing the genetics of the modern dairy cow to continue improvements in feed efficiency. J. Dairy Sci. 99:4941-4954.

Volden, H. 2011. NorFor-The Nordic Feed Evaluation System. EAAP publication no. 130. Wageningen Academic Publishers, Wageningen, the Netherlands.

Volden, H., and N. I. Nielsen. 2011. Energy and metabolizable protein supply. Pages 81-84 in NorFor-The Nordic Feed Evaluation System. EAAP publication no. 130. H. Volden, ed. Wageningen Academic Publishers, Wageningen, the Netherlands.

Waghorn, G. C., and R. S. Hegarty. 2011. Lowering ruminant methane emissions through improved feed conversion efficiency. Anim. Feed Sci. Technol. 166-167:291-301.

Yan, T., C. S. Mayne, F. G. Gordon, M. G. Porter, R. E. Agnew, D. C. Patterson, C. P. Ferris, and D. J. Kilpatrick. 2010. Mitigation of enteric methane emissions through improving efficiency of energy utilization and productivity in lactating dairy cows. J. Dairy Sci 93:2630-2638 